\title{
$\underset{\mathbf{a} \rho}{\mathrm{a} \rho} \boldsymbol{\rho} \mu$
}

Al-Jabar: Jurnal Pendidikan Matematika

Vol. 6, No. 2, 2015, Hal 195 - 202

\section{Brain-Based Learning untuk Meningkatkan Literasi Matematis Siswa}

\author{
Iwan Kuswidi \\ UIN Sunan Kalijaga Yogyakarta: iwankuswidi@gmail.com
}

Submitted : 07-06-2015, Revised : 21-11-2015, Accepted : 16-12-2015

\begin{abstract}
This research is a literature research that studies, analyzes and concludes literature and previous research on brain-based learning which expended by considering how the brain works. Then discuss and review of student's mathematical literacy which is the ability to formulate, implement and interpret mathematics in a variety of contexts, including the mathematical reasoning ability and using the concepts, procedures, and facts to describes, explain or predict the phenomena/events. Furthermore discuss how the impact of brain-based learning to improve students' mathematical literacy.
\end{abstract}

Keyword: Brain-based; Learning, Literacy; Mathematical

\begin{abstract}
Abstrak
Penelitian ini merupakan kajian teori yang menelaah, menganalisis dan menyimpulkan literatur-literatur dan penelitian-penelitian terdahulu tentang brain-based learning yang dikembangkan dengan mempertimbangkan cara kerja otak. Kemudian membahas dan mengkaji tentang kemampuan literasi matematis siswa yang merupakan kemampuan siswa untuk merumuskan, menerapkan dan menafsirkan matematika dalam berbagai konteks, termasuk kemampuan melakukan penalaran secara matematis dan menggunakan konsep, prosedur, dan fakta untuk menggambarkan, menjelaskan atau memperkirakan fenomena/kejadian. Lebih lanjut kemudian membahas bagaimana keterkaitan brain-based learning dalam rangka untuk meningkatkan kemampuan literasi matematis siswa.
\end{abstract}

Kata kunci: Brain-based; Learning, Literasi; Matematis

\section{PENDAHULUAN}

Sejak masa lalu hingga masa sekarang, kemampuan literasi atau kemampuan membaca dan menulis merupakan kompetensi utama yang dibutuhkan dalam melakukan kegiatan sehari-hari. Tanpa kemampuan literasi, komunikasi antar manusia sulit berkembang ke taraf yang lebih tinggi. Kandungan dan gagasan umum dari makna literasi tersebut diserap dalam bidang matematika yang memunculkan istilah literasi matematis.

Pada masyarakat umum, matematika sering diartikan sebagai bahasa simbol atau bilangan. Lebih sederhana lagi yang terjadi di masyarakat, matematika seringkali dikaitkan hanya dengan angka atau operasi hitung, misalnya: penjumlahan, pengurangan, perkalian, dan pembagian. Adapun makna literasi matematis sebenarnya diartikan sebagai kemampuan seseorang untuk merumuskan, menerapkan dan menafsirkan matematika dalam berbagai konteks, termasuk kemampuan melakukan penalaran secara matematis dan menggunakan konsep, prosedur, dan fakta untuk menggambarkan, menjelaskan atau memperkirakan fenomena/kejadian. Literasi matematis membantu seseorang untuk memahami peran atau kegunaan matematika di dalam kehidupan sehari-hari sekaligus menggunakannya untuk 


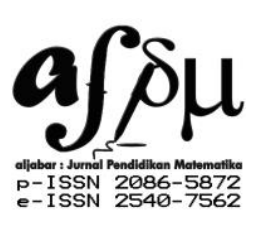

\section{Al-Jabar: Jurnal Pendidikan Matematika Vol. 6, No. 2, 2015, Hal 195 - 202}

membuat keputusan-keputusan yang tepat sebagai warga negara yang membangun, peduli dan berpikir.

Untuk mencapai kemampuan literasi matematis seperti yang tersebut di atas, beberapa metode pembelajaran dipakai atau dicoba diterapkan. Salah satu yang memungkinkan untuk diterapkan adalah dengan brain-based learning. Hal ini dikarenakan literasi matematis memberikan porsi yang besar bagi otak untuk berpikir secara menyeluruh dan komplek sedangkan brain-based learning adalah pembelajaran yang diselaraskan dengan cara kerja otak yang didesain secara alamiah untuk belajar. Lebih lanjut dijelaskan bahwa brain-based learning merupakan strategi pembelajaran didasarkan pada prinsip-prinsip yang berasal dari suatu pemahaman tentang otak.

Selanjutnya, seperti apakah brain-based learning, literasi matematis, dan bagaimanakah brain-based learning yang dapat meningkatkan literasi matematis? Berikut akan dibahas dan dipaparkan penjelasannya.

\section{METODE PENELITIAN}

Penelitian ini menggunakan metode studi literatur, yaitu melakukan pengkajian terhadap teori-teori pembelajaran, buku, artikel, penelitian lain, yang berkaitan dengan materi kemudian dianalisis, didiskusikan, disarikan da n disusun dalam bentuk artikel laporan.

\section{HASIL PENELITIAN DAN PEMBAHASAN \\ Brain-based Learning}

Pengertian brain-based learning, menurut Eric Jensen (Nurhadyani, 2010) adalah pembelajaran yang diselaraskan dengan cara kerja otak yang didesain secara alamiah untuk belajar. Lebih lanjut, dijelaskan bahwa brain-based learning merupakan strategi pembelajaran didasarkan pada prinsip-prinsip yang berasal dari suatu pemahaman tentang otak (Jensen, 2011).

Menurut hasil riset yang dinyatakan oleh K. Barbara Given (Setiahati, 2008), bahwa otak mengembangkan lima sistem pembelajaran primer yaitu: (1) Sistem pembelajaran emosional, (2) Sistem pembelajaran sosial, (3) Sistem pembelajaran kognitif, (4) Sistem pembelajaran fisik, dan (5) Sistem pembelajaran reflektif.

Mengenai perancangan pembelajaran brain-based learning, Andi Basuki Prima Birawa (Birawa, 2011) menyebutkan ada 12 prinsip perancangannya, yaitu: (1) Perkaya lingkungan yang menstimulasi, (2) Tempat untuk belajar secara kelompok, (3) Menghubungkan lokasi dalam ruang dan luar ruangan, (4) Koridor dan ruang publik terdiri dari simbol komunitas sekolah bukan hanya slogan, (5) Tempat yang aman, (6) Tempat yang bervariasi, (7) Perubahan display, (8) Miliki semua sumber yang mungkin diperlukan, (9) Fleksibilitas, (10) Tempat untuk aktif/pasif, (11) Ruang personal, (12) Komunitas masyarakat.

Sedangkan menurut Asep Sapa'at (Sapa'at, 2007), ada tiga strategi utama yang dikembangkan dalam implementasi brain-based learning, yaitu: (1) Menciptakan lingkungan yang menantang kemampuan berpikir siswa, (2) Menciptakan lingkungan pembelajaran yang menyenangkan, (3) Menciptakan situasi pembelajaran yang aktif dan bermakna bagi siswa.

Adapun garis besar perencanaan pembelajaran brain-based learning menurut Eric Jensen (Jensen, 2011) terdapat tujuh tahap, yaitu: (1) Pra-Paparan, (2) Persiapan, (3) Inisiasi 


\section{Al-Jabar: Jurnal Pendidikan Matematika Vol. 6, No. 2, 2015, Hal 195 - 202}

dan Akuisisi, (4) Elaborasi, (5) Inkubasi dan Pengkodean Memori, (6) Verifikasi dan Pengecekan Kepercayaan, (7) Selebrasi dan Integrasi.

Penjelasan tentang tahapan perencanaan pembelajaran brain-based learning sebagai berikut:

Tahap 1 (Pra-Paparan)

Lebih berperan sebagai pengkondisian siswa dan menjadikannya kenal dan siap dengan Guru dan materi. Pada tahap ini, diberikan ulasan tentang pembelajaran baru sebelum menggali lebih jauh dalam pembelajaran. Antaralain dapat dilakukan dengan: memajang peta konsep tentang materi yang akan dipelajari beberapa hari sebelum pembelajaran dimulai, membangun hubungan yang positif antara Guru dengan siswa, melakukan senam otak.

Tahap 2 (Persiapan)

Guru memberikan penjelasan awal mengenai materi yang akan dipelajari dan mengaitkan materi dengan kehidupan sehari-hari.

Tahap 3 (Inisiasi dan Akuisisi)

Merupakan tahap penciptaan koneksi antar neuron-neuron otak. Pada tahap ini, Guru membagi siswa menjadi beberapa kelompok dan memberikan LKS untuk diisi dan didiskusikan siswa.

Tahap 4 (Elaborasi)

Adalah tahap yang memberikan kesempatan kepada otak untuk menyortir, menyelidiki, menganalisis, menguji, dan memperdalam pelajaran. Pada tahap ini, siswa mempresentasikan hasil diskusi kelompok di depan kelas, sedangkan siswa yang lain memperhatikan, mengungkapkan pendapat, atau menyampaikan pertanyaan. Diharapkan siswa dapat menemukan jawaban yang tepat, karena itu Guru harus membimbing siswa dalam berdiskusi.

Tahap 5 (Inkubasi dan Pengkodean Memori)

Menekankan bahwa waktu istirahat dan mengulang kembali merupakan hal yang penting. Pada tahap ini siswa dapat melakukan peregangan otak, dapat dilakukan antara lain dengan menonton video yang dapat memotivasi belajar. Selain itu, Guru juga memberikan soal latihan sederhana yang berkaitan dengan materi yang baru dipelajari.

Tahap 6 (Verifikasi dan Pengecekan Keyakinan)

Merupakan tahap untuk mengetahui apakah siswa sudah paham dengan materi yang dipelajari. Siswa juga perlu tahu apakah dirinya sudah paham atau belum. Pada tahap ini, Guru memberikan soal latihan yang setingkat lebih rumit. Siswa mengerjakan soal dengan bimbingan Guru.

Tahap 7 (Selebrasi dan Integrasi)

Menanamkan semua arti penting dari kecintaan terhadap belajar. Pada tahap ini sangat penting untuk melibatkan emosi, sehingga dibuat ceria dan menyenangkan. Pada tahap ini siswa dengan bimbingan Guru menyimpulkan materi yang baru dipelajari, kemudian Guru memberikan tugas rumah dan memberi tahu materi yang akan dipelajari selanjutnya. Sebagai penutup, Guru bersama dengan siswa melakukan perayaan kecil, seperti bersorak dan bertepuk tangan bersama. 


\section{Al-Jabar: Jurnal Pendidikan Matematika \\ Vol. 6, No. 2, 2015, Hal 195 - 202}

Tahapan-tahapan pembelajaran di atas merupakan langkah-langkah inti dalam metode ini, adapun kegiatan-kegiatan pada setiap langkahnya dapat dikembangkan lebih variatif.

\section{Literasi Matematis}

Literasi sering disebut dengan "melek huruf" yang merupakan kebalikan dari illiterasi "buta huruf" dan juga sering dihubungkan dengan huruf atau aksara. Literasi merupakan serapan dari kata dalam bahasa inggris "literacy", yang artinya kemampuan untuk membaca dan menulis.

Definisi literasi matematis menurut draft assessment framework PISA (2012):

Mathematical literacy is an individual's capacity to formulate, employ, and interpret mathematics in a variety of contexts. It includes reasoning mathematically and using mathematical concepts, procedures, facts, and tools to describe, explain, and predict phenomena. It assists individuals to recognise the role that mathematics plays in the world and to make the well-founded judgments and decisions needed by constructive, engaged and reflective citizens.

Berdasarkan definisi tersebut, literasi matematis diartikan sebagai kemampuan seseorang untuk merumuskan, menerapkan dan menafsirkan matematika dalam berbagai konteks, termasuk kemampuan melakukan penalaran secara matematis dan menggunakan konsep, prosedur, dan fakta untuk menggambarkan, menjelaskan atau memperkirakan fenomena/kejadian. Literasi matematis membantu seseorang untuk memahami peran atau kegunaan matematika di dalam kehidupan sehari-hari sekaligus menggunakannya untuk membuat keputusan-keputusan yang tepat sebagai warga negara yang membangun, peduli dan berpikir. Soal-soal matematika dalam studi PISA lebih banyak mengukur kemampuan menalar, memecahkan masalah dan berargumentasi daripada soal-soal yang mengukur kemampuan teknis baku yang berkaitan dengan ingatan dan perhitungan semata.

Menurut Kusumah (2010), literasi terkait dengan keterampilan komunikasi tertulis, yang mencakup kemampuan membaca dan menulis huruf. Dengan demikian, kita menganggap seseorang termasuk buta huruf (mathematically illiterate) jika dia tidak mampu membaca dan menulis. Literasi matematis ini merupakan dampak adanya tuntutan yang mendorong masyarakat harus bertahan hidup di bawah budaya dan peradaban yang dimilikinya. Kini keterampilan membaca, menulis, dan berhitung (aritmetika) tidaklah cukup untuk menghadapi masalah yang semakin rumit dan sulit dalam kehidupan sehari-hari. Dalam matematika kita harus memahami pula hubungan atau keterkaitan di antara dua objek atau lebih.

De Lange (2003), menyatakan bahwa literasi matematis tidak sebatas mencakup kemampuan melaksanakan sejumlah cara atau prosedur, dan memiliki pengetahuan dasar matematis yang memungkinkan seorang anggota masyarakat mampu hidup dalam suatu situasi yang sulit, dan cukup dengan hanya yang mereka perlukan, tetapi juga mencakup pengetahuan, metode, dan proses matematis, yang dimanfaatkan dalam berbagai konteks dengan cara yang memberi inspirasi dan membuka wawasan pemikiran. Karena literasi matematis mempunyai implikasi pada kemampuan lainnya, literasi ini sangat penting, terutama yang mencakup aspek numerik, kuantitatif, dan ruang. Masing-masing literasi ini 


\section{Al-Jabar: Jurnal Pendidikan Matematika Vol. 6, No. 2, 2015, Hal 195 - 202}

akan memberdayakan seseorang dalam memaknai aspek kehidupan dunia. Literasi matematis sifatnya kurang formal tetapi lebih intuitif, kurang abstrak te tapi lebih kontekstual, kurang banyak simbol tetapi lebih konkrit. Literasi matematis terfokus pada kemampuan penalaran, berpikir, dan interpretasi, di samping kemampuan-kemampuan matematis lainnya.

Pusat Pengembangan dan Pemberdayaan Pendidik dan Tenaga Kependidikan Matematika (P4TK, 2011) mendefinisikan bahwa, "Literasi matematis adalah kemampuan seseorang untuk merumuskan, menerapkan dan menafsirkan matematika dalam berbagai konteks, termasuk kemampuan melakukan penalaran secara matematis dan menggunakan konsep, prosedur, dan fakta untuk menggambarkan, menjelaskan atau memperkirakan fenomena/kejadian". Definisi literasi matematis tidak sekadar terfokus pada pengetahuan minimal dalam matematika. Literasi tersebut juga mencakup "doing mathematics" dan menggunakan konsep matematis dalam bidang lainnya dan dalam aspek kehidupan seharihari. Dari yang biasa hingga yang tidak biasa, dari yang sederhana hingga yang kompleks.

Dari pendapat-pendapat di atas, literasi matematis dapat diartikan sebagai kemampuan seseorang untuk merumuskan, menerapkan dan menafsirkan matematika dalam berbagai konteks, termasuk kemampuan melakukan penalaran secara matematis dan menggunakan konsep, prosedur, dan fakta untuk menggambarkan, menjelaskan atau memperkirakan fenomena/kejadian.

PISA mentransformasikan prinsip-prinsip literasi matematis menjadi tiga komponen yaitu konten, proses dan konteks. Selanjutnya komponen-komponen literasi matematis tersebut dijelaskan oleh P4TK (2011) yaitu sebagai berikut:

(1) Komponen konten

dimaknai sebagai isi atau materi atau obyek pelajaran matematika yang dipelajari di sekolah yaitu meliputi perubahan dan keterkaitan, ruang dan bentuk, kuantitas, dan ketidakpastian data.

(2) Komponen proses

dimaknai sebagai hal-hal atau langkah-langkah seseorang untuk menyelesaikan suatu permasalahan dalam situasi atau konteks tertentu dengan menggunakan matematika sebagai alat sehingga permasalahan itu dapat diselesaikan. Kemampuan proses dapat didefinisikan sebagai kemampuan seseorang dalam merumuskan (formulate), menggunakan (employ) dan menafsirkan (interpret) matematika untuk memecahkan masalah yang melibatkan kemampuan dalam komunikasi, matematisasi, representasi, penalaran dan argumentasi, menentukan strategi untuk memecahkan masalah, penggunaan bahasa simbol, bahasa formal, dan bahasa teknis sebagai alat matematika.

Selanjutnya kerangka penilaian literasi matematis dalam PISA 2012 menyebutkan bahwa kemampuan proses melibatkan 7 hal penting sebagai berikut: (a) Communication, yaitu mengkomunikasikan masalah hingga mengkomunikasikan penyelesaiannya, (b) Mathematising, yaitu mengubah (transform) permasalahan dari dunia nyata ke bentuk matematika dan sebaliknya, (c) Representation, yaitu menyajikan kembali suatu permasalahan atau suatu obyek matematika melalui hal-hal seperti: memilih, menafsirkan, menerjemahkan, dan mempergunakan grafik, tabel, gambar, diagram, rumus, persamaan, maupun benda konkret untuk memotret permasalahan sehingga lebih jelas, (d) Reasoning and Argument, yaitu kemampuan menalar dan memberi alasan yang berakar pada kemampuan berpikir secara logis untuk melakukan analisis terhadap informasi untuk 


\section{Al-Jabar: Jurnal Pendidikan Matematika Vol. 6, No. 2, 2015, Hal 195 - 202}

menghasilkan kesimpulan yang beralasan. (e) Devising Strategies for Solving Problems, yaitu kemampuan menggunakan strategi untuk memecahkan masalah, (f) Using Symbolic, Formal and Technical Language and Operation, (g) Using Mathematics Tools, yaitu kemampuan menggunakan alat-alat matematika, misalnya melakukan pengukuran, operasi dan sebagainya.

(3) Komponen konteks,

yaitu situasi yang tergambar dalam suatu permasalahan yang diujikan yang dapat terdiri atas konteks pribadi (personal), konteks pekerjaan (occupational), konteks sosial (social) dan konteks ilmu pengetahuan (scientific).

Hasil kajian Maryanti menyatakan bahwa secara spesifik, penilaian literasi matematis yang dilakukan dalam studi PISA terdiri dalam 6 level atau tingkatan. Untuk soal literasi level 1 dan level 2 merupakan kelompok soal dengan skala paling bawah. Soal literasi level 3 dan level 4 termasuk dalam kelompok soal dengan skala menengah, sedangkan soal literasi level 5 dan level 6 merupakan kelompok soal dengan skala tinggi (Maryanti, 2012). Adapun kemampuan yang diukur dari masing-masing level adalah sebagai berikut:

(1) Level 1

Kemampuan yang diukur adalah kemampuan siswa menjawab pertanyaan-pertanyaan yang mencakup konteks-konteks yang familiar. Siswa dapat mengidentifikasi informasi dan menyelesaikan prosedur-prosedur yang rutin mengacu pada instruksi-instruksi langsung dalam situasi yang eksplisit dan disajikan secara jelas. Siswa juga dituntut untuk dapat melakukan tindakan-tindakan yang nyata dan mengikuti stimulus yang diberikan.

(2) Level 2

Kemampuan yang diukur adalah kemampuan siswa untuk menginterpretasikan dan mengenali situasi dalam konteks yang memerlukan intervensi langsung. Mereka dalam memilih informasi yang relevan dari sumber tunggal dan menggunakan cara representasi tunggal.

(3) Level 3

Kemampuan yang diukur yaitu siswa dituntut memiliki kemampuan untuk dapat melaksanakan prosedur dengan baik, termasuk prosedur yang memerlukan keputusan secara beruntun. Siswa dapat memilih dan menerapkan strategi pemecahan masalah yang sederhana.

(4) Level 4

Kemampuan yang diukur yaitu kemampuan siswa bekerja secara efektif dengan model dan situasi konkret tetapi kompleks. Siswa dapat memilih dan mengintegrasikan dan representasi yang berbeda dan menghubungkan ke dalam dunia nyata.

(5) Level 5

Siswa dituntut untuk dapat bekerja dengan model untuk situasi yang kompleks, mengidentifikasi kendala yang dihadapi dan melakukan dugaan-dugaan. Mereka dapat memilih, membandingkan, dan mengevaluasi sesuai dengan strategi pemecahan masalah dalam menghadapi masalah-masalah kompleks yang berhubungan dengan model tersebut.

(6) Level 6

Kemampuan yang diukur yaitu kemampuan siswa untuk dapat mengkonsep, menggeneralisasi dan memanfaatkan informasi berdasarkan penyelidikan dan 


\section{Al-Jabar: Jurnal Pendidikan Matematika Vol. 6, No. 2, 2015, Hal 195 - 202}

pemodelan dalam situasi masalah yang kompleks. Siswa dapat menghubungkan sumbersumber informasi yang berbeda dengan fleksibel dan menerjemahkannya.

\section{Meningkatkan Literasi Matematis melalui Brain-based Learning}

Ada poin-poin penting dalam kemampuan literasi matematis, yaitu mampu merumuskan permasalahan konteks, mampu menerapkan (menggunakan konsep, prosedur, dan fakta), mampu menafsirkan matematika dalam berbagai konteks, dan mampu melakukan penalaran secara matematis.

Kemampuan merumuskan permasalahan konteks dapat dilatihkan dengan menciptakan lingkungan yang menantang kemampuan berpikir serta tahap elaborasi yang memberikan kesempatan kepada otak untuk menyortir, menyelidiki dan menganalisis materi pembelajaran.

Adapun kemampuan menerapkan (menggunakan konsep, prosedur, dan fakta), mampu menafsirkan matematika dalam berbagai konteks, dan mampu melakukan penalaran secara matematis dapat dipacu pada tahap pembelajaran elaborasi yaitu dengan memberikan kesempatan kepada otak untuk menyortir, menyelidiki, menganalisis, menguji, dan memperdalam materi pelajaran serta didukung oleh penciptaan situasi pembelajaran yang aktif dan bermakna serta diperkuat dengan tuntutaan diskusi yang mengharuskan siswa berlatih menyampaikan ide/gagasan dan penyelesaian, mempertahankan argumen serta mengkritisi atau menganalisis ide yang disampaikan teman diskusi.

Terakhir yang perlu dipahami, bahwa dalam brain-based learning tidak dapat dipisahpisahkan tahapan pembelajarannya (tidak dapat diambil sebagian) dan bahkan tahap pembelajarannya harus urut, hal ini untuk menjamin maksimalnya penguasaan siswa dalam memahami matematika. Lebih lagi pada kemampuan literasi siswa dituntut untuk utuh dalam memahami matematika dari yang mendasar hingga konsep dan penerapannya dalam konteks nyata.

\section{SIMPULAN DAN SARAN}

Brain-based learning memiliki 7 langkah pembelajaran yaitu: Pra-Paparan (memberi tinjauan pembelajaran baru), Persiapan (menciptakan keingintahuan), Inisiasi dan Akuisisi (penciptaan koneksi neuron otak), Elaborasi (pengolahan informasi), Inkubasi dan Pengkodean Memori (mengendapkan pengetahuan), Verifikasi dan Pengecekan Kepercayaan (pengecekan pengetahuan siswa), Selebrasi dan Integrasi (pelibatan emosi dan kegembiraan).

Literasi matematis adalah kemampuan seseorang untuk merumuskan, menerapkan dan menafsirkan matematika dalam berbagai konteks, termasuk kemampuan melakukan penalaran secara matematis dan menggunakan konsep, prosedur, dan fakta untuk menggambarkan, menjelaskan atau memperkirakan fenomena/kejadian.

Dengan menggunakan brain-based learning, maka akan memungkinkan untuk mengembangkan literasi matematis, pada langkah persiapan yang melatih keingintahuan akan merangsang kemampuan menyelidiki dan menafsirkan permasalahan matematika dari berbagai konteks, pada langkah elaborasi akan mengarahkan kepada merumuskan dan menerapkan penalaran secara matematis dan menggunakan konsep, prosedur dan fakta untuk menjelaskan atau memperkirakan permasalahan dan penyelesaiannya. 
Berdasarkan pada kajian dan kesimpulan di atas, maka untuk membuktikan efektifitas dan menguji keberhasilannya perlu dilakukan penelitian lanjutan atau penelitian lapangan yang melibatkan siswa secara langsung.

\section{DAFTAR PUSTAKA}

Birawa, A. B. P. (2011). Program Pembelajaran Berbasis Otak untuk Meningkatkan Kreativitas pada Anak Usia Dini. Disertasi pada S3 Pengembangan Kurikulum SPS UPI: Tidak diterbitkan.

De Lange, J. (2003). Mathematics for Literacy, In Quantitative Literacy, Why Numeracy Matters for Schools and Colleges. Proceeding of the National Forum on Quantitative Literacy. Washington D.C: National Academy of Sciences.

Jensen, E. (2011). Pemelajaran Berbasis Otak: Paradigma Pengajaran Baru. Jakarta: PT Indeks. Kusumah, Y. S. (2010). Literasi Matematis. Bandung: Universitas Pendidikan Indonesia.

Maryanti, E. (2012). Peningkatan Literasi Matematis Siswa melalui Pendekatan Metacognitive Guidance. Tesis pada SPS UPI Bandung: tidak diterbitkan.

Nurhadyani, D. (2010). Penerapan Brain Based Learning dalam Pembelajaran Matematika untuk Meningkatkan Motivasi Belajar dan Kemampuan Koneksi Matematis Siswa (Studi Eksperimen terhadap Siswa Kelas IX Suatu SMP Negeri di Kabupaten Bandung). Skripsi pada S1 FPMIPA UPI: Tidak diterbitkan.

P4TK. 2011. Instrumen Penilaian Hasil Belajar Matematika SMP: Belajar dari PISA dan TIMSS. Yogyakarta: P4TK. Kemendiknas.

Sapa'at, A. (2007). Brain-Based Learning. [Online] Tersedia di http://matematika.upi.edu/index.php/brain-based-learning/

Setiahati. (2008). Brain-Based Learning dalam Pembelajaran Matematika untuk Meningkatkan Kemampuan Pemecahan Masalah Matematik Siswa SMA. Skripsi pada S1 FPMIPA UPI: Tidak diterbitkan.

Stacey, K. (2012). The International Assessment of Mathematical Literacy: PISA 2012 Framework and Items. Journal 12th International Congress on Mathematical Education Program. 